\title{
SOMATIC AND OTHER BIOLOGICAL ASPECTS OF COVID-19 VACCINATION: LEGAL MEASURES TO SUPPORT SOCIETY AND BUSINESS DURING THE POST-PANDEMIC ERA IN RUSSIA
}

\begin{abstract}
ASPECTOS SOMÁTICOS E OUTROS ASPECTOS BIOLÓGICOS DA VACINAÇÃO COVID-19: MEDIDAS LEGAIS PARA APOIAR A SOCIEDADE E OS NEGÓCIOS DURANTE A ERA PÓS-PANDEMIA NA RÚSSIA
\end{abstract}

\section{Elena Evgenyevna Gulyaeva²}

\section{Elena Nikolaevna Trikoz ${ }^{3}$}

Licença CC BY:

Artigo distribuído sob os termos Creative Commons, permite uso e distribuição irrestrita em qualquer meio desde que o autor credite a fonte original.

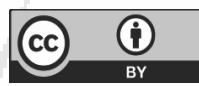

\begin{abstract}
The purpose of the review is to comprehend the current trends in emergency rule-making in Russia and the restrictive practices introduced in the context of the COVID-19 pandemic. In response to new challenges, the Russian authorities have developed a kind of "rule-making vaccine". The introduction of new legislation, especially at the local level of Russian Federation, was accompanied by both long-term state support of business structures and the "freezing of the Russian economy." The situation of "unofficial testing" of a vaccine against COVID-19, facts of violation of the fundamentals of clinical trials, the norms of Russian legislation and generally recognized international standards in the field of clinical testing of drugs are analyzed. According to the position of the World Health Organization (WHO) the right to health imposes on the States a legal obligation to ensure timely access to adequate levels of high-quality health care, clean and safe drinking water, sanitation, adequate nutrition, shelter, healthrelated information and education, gender equality. As a result, the considerable amount of attention is paid to the analysis of the content of general and specific legal instruments at the national level to Support Society and Business During the

Post-Pandemic Era in Russia.
\end{abstract}

Key words: COVID-19, human rights, biolaw, biopolitics, vaccination, ethical standards, legal regulation

\footnotetext{
1 Part of this research conducted by the co-author of the article is Elena N. Trikoz, has been supported by RFBR (the project No. 18-29-14100).

2 Diplomatic Academy of the Ministry of Foreign Affairs of the Russian Federation - Russia.

3 Moscow State Institute of International Relations University; RUDN University - Russia.
} 
Resumoo objetivo da artigo é compreender as tendências atuais na formulação de regras de emergência na Rússia e as práticas restritivas introduzidas no contexto da pandemia COVID-19. Em resposta aos novos desafios, as autoridades russas desenvolveram uma espécie de "vacina que cria regras". A introdução de uma nova legislação, especialmente no nível local da Federação Russa, foi acompanhada por um apoio estatal de longo prazo às estruturas de negócios e pelo "congelamento da economia russa". Analisa-se a situação de "teste não oficial" de uma vacina contra COVID-19, fatos de violação dos fundamentos dos testes clínicos, as normas da legislação russa e os padrões internacionais geralmente reconhecidos no campo dos testes clínicos de medicamentos. De acordo com a posição da Organização Mundial da Saúde (OMS), o direito à saúde impõe aos Estados a obrigação legal de garantir o acesso oportuno a níveis adequados de cuidados de saúde de alta qualidade, água potável limpa e segura, saneamento, nutrição adequada, abrigo, informação e educação em saúde, igualdade de gênero. Como resultado, uma quantidade considerável de atenção é dada à análise do conteúdo de instrumentos jurídicos gerais e específicos em nível nacional para apoiar a sociedade e os negócios durante a era pós-pandêmica na Rússia.

Palavras-chave: COVID-19, direitos humanos, biodireito, biopolítica, vacinação, padrões éticos, regulamentação legal.

\section{INTRODUCTION}

According to the nomenclature of the World Health Organization (WHO) and the International Committee on Taxonomy of Viruses (ICTV), the virus from the Chinese city of Wuhan was given an official name "severe acute respiratory syndrome coronavirus 2 (SARS-CoV-2)" and the disease it caused was called "coronavirus disease (COVID-19)" (see the ICTV decision of February 11, 2020).

From the legal point of view, this fact is non-trivial since having included COVID-19 into the International Classification of Diseases (ICD), the WHO has the right to announce measures for maintaining emergency preparedness and urge the countries of the world to respond to the disease. For example, on March 11, 2020, the WHO declared the first coronavirus pandemic in history. This pandemic can be controlled but it is impossible to avoid adverse consequences for the global economy and trade.

On March 30, 2020, a joint statement of the directors-general of FAO, the WHO, and WTO on mitigating impacts of COVID-19 on food trade and markets was adopted. In this statement, the states of the world were encouraged to "...ensure that information on food-related trade measures, levels of food production, consumption, and stocks, as well as on food prices, is available to all in real time", to allow "... producers, consumers and traders to make informed decisions", as well as to contain "panic buying and the hoarding of food and other essential items"4.

The coronavirus disease quickly spread over the planet, covering more than 200 countries of the world. Some of them (China, the United States, Japan, Brazil, Russia, Italy, Spain, Iran, etc.)

4 For more information see: <www.who.int/news-room/detail/30-03-2020-joint-statement-by-qu-dongyu-tedrosadhanom-ghebreyesus-and-roberto-azevedo-directors-general-of-the-food-and-agriculture-organization-of-theunited-nations-(fao)-the-world-health-organization-(who)-and-the-world-trade-organization-(wto)>. 
took unprecedented measures to combat the coronavirus through quarantine and the restriction of human rights. On September 11, 2020, the UN General Assembly adopted an omnibus resolution on a comprehensive and coordinated response to the COVID-19 pandemic. The resolution was supported by 169 countries, including Russia, only the USA and Israel were opposed to it.

In March 2020, Russia faced the escalation of the coronavirus problem. That is why the federal government sealed off the external borders and introduced regional lockdowns. The lockdowns meant a strong recommendation to the citizens to voluntarily stay home and a ban on going to work, school, or public places. Russian regional authorities ordered to close public places (except for groceries and drugstores), introduced distance learning in all schools, made employers transfer riskgroup employees to a remote working regime, and imposed sanctions for organizations (enterprises) for violating the "high-alert mode"

The COVID-19 measures resulted in the serious deterioration of the Russian economy. The crisis was accompanied by the global stock market crash, lower economic activity, and labor market collapse. The price war between Russia and Saudi Arabia on the hydrocarbon market, wide swings in oil prices, and other downsides also contributed to the critical situation. Russian businesses were severely tested; many organizations (enterprises) were facing bankruptcy. Not every organization could adapt to the remote working regime (it was true for cafes, restaurants, libraries, parks, etc.). Many businesses had to suspend their activities (tour operators, air carriers, betting shops, cinemas, fitness clubs, beauty parlors, etc.).

At the same time, the pandemic lockdown in Russia triggered a high demand for streaming platforms content and remote services (the delivery of foods, disinfectants, and other products). The issue of supporting the citizens in the face of mass unemployment and the general crisis of the Russian economy became particularly urgent.

\section{LEGAL MEASURES TO SUPPORT SOCIETY AND BUSINESS}

The Russian authorities actively responded to the new challenges of COVID-19. They developed a kind of "rule-making vaccine", i.e. introduced a package of measures to combat the coronavirus economic impact. The measures were developed with the opinions of the business community in mind, including the Chamber of Commerce and Industry of the Russian Federation. A COVID-19 Law, i.e. the Federal Law on Amending Certain Legislative Acts of the Russian Federation Related to Disaster Prevention and Management was adopted on April 1, $2020^{6}$.

5 See, for example, the Decree of the Moscow Mayor on the Introduction of the High-Alert Mode of March 5, 2020; the Moscow Law on Amending Articles 2 and 8 of the Moscow Law on the Focal Points for the Protection of Law and Order in Moscow of December 10, 2003, and the Moscow Administrative Code of November 21, 2007; the Decree of the Governor of the Pskov Oblast on Measures to Counter the New Coronavirus Disease (2019-nCoV) in Pskov Oblast of March 15, 2020, etc.

6 For more information see: <http://base.garant.ru/73828134/>. 
In April 2020, the Russian President Vladimir Putin signed important federal laws, including the empowerment of the Russian federal government with the opportunity to declare the state of emergency or the high-alert mode. The reason for the declaration could be the spread of hazardous diseases. The government also got the right to establish rules, which Russian organizations (enterprises) would have to follow under the described circumstances. The President also signed a Decree on the Prolongation of a Non-Working Days Period in Russia. The regional leaders got additional powers to determine how rigid their regional lockdowns were going to be (for example, companies' activities suspension, regardless of the ownership structure) and it raised additional concerns among economists ${ }^{7}$. At the same time, Russian businesses, which suffered from the lockdown more than others, got repayment holidays. The Government Commission identified 22 industries to provide them with targeted state support ${ }^{8}$.

A new term "national guarantee system for supporting small and medium-sized businesses" appeared. It means systematic private obligations guarantees (protection) for businesspersons who are using bank loans and other financial resources ${ }^{9}$. Bankruptcies of small and medium-sized businesses at creditors' requests, rent increases (when the premises are state-owned), tax audits, customs inspections, and other investigations of this type are going to be suspended up to the end of 2020 .

The Federal Priority Action Plan of March 17, 2020 covers system-wide measures to support the economy. Among other tools, there are such benefits as the abolition of several types of fine; adjustment of prices under government contracts because of the coronavirus effects; tax (fee) referrals and installments; loan restructuring; subsidizing loan rates for housing developers; support for leasing companies; partial compensation of losses to national sports federations; more work permits for foreign employees, etc. Plus the operational monitoring of the financial and economic situations in the so-called 'backbone organizations' of the Russian economy (approximately 600 companies) was introduced. The government also decided to review several bilateral agreements to avoid double taxation ${ }^{10}$.

$7 \quad$ The analytics from the Macroeconomic Analysis Center believe that the immediate effect of the non-working days period would amount to about 20 percent of GDP decrease, i.e., the country would lose almost 18 trillion rubles. See: YASTREBOVA, S; MAREMINSKAYA, E. The Prolongation of the Non-Working Days Period Can Lead to Job Cuts and Bankruptcies, in Vedomosti, April 2, 2020.

8 For more information see: <www.economy.gov.ru/material/file/be6cf04db17a6caed6bfa9fd97684d7b/26032020. pdf $>$.

9 The Federal Law of April 1, 2020 on Amending the Federal Law on the Development of Small and MediumSized Businesses in the Russian Federation to Improve the National Guarantee System for Supporting Small and Medium-Sized Businesses.

10 MALINOVSKY, A. A; OSINA, D.M; TRIKOZ, E.N; State Support for the Russian Economy Affected by Covid-19 Consequences (Legal Aspects), in ASHMARINA, S; MANTULENKO, V; VOCHOZKA, M. (eds). Engineering Economics: Decisions and Solutions from Eurasian Perspective. Engineering Economics Week 2020, Lecture Notes in Networks and Systems, vol. 139, Cham: Springer. 2021, p. 283-287. 
The Supreme Court of the Russian Federation issued special guidelines to explain the way laws should be applied during the pandemic. ${ }^{11}$ The document covered contracts, force majeure, statutes of limitations, procedural deadlines, and bankruptcies as well as criminal and administrative responsibilities. Everyone could postpone the fulfillment of obligations after the pandemic had become a force majeure for a debtor (Article 401 (3) of the Russian Civil Code). Nevertheless, the debtor had to prove that the force majeure existed and it had been provoked by the pandemic. The debtor also had to show that he/she had taken reasonable measures to diminish the harmful consequences. Besides, the procedural deadlines included the non-working days, i.e. the claims were accepted during the lockdown. People were allowed to start the proceedings, even if the deadlines had been missed because of coronavirus. In the end, the Supreme Court explained what was meant by the automatic moratorium on bankruptcies and it did not matter if the bankruptcies had nothing to do with the pandemic. This approach differed from the one that was used, for example, in Germany.

The legally recognized "shock freezing of the Russian economy" during the COVID-19 pandemic caused lots of problems for many businesses, they did not survive the suspension and went bankrupt. The credit portfolios of large Russian banks got worse. Anyway, the government understood how important it was to restructure private and corporate loans on time.

\section{LEGAL AND BIOLOGICAL ASPECTS OF COVID-19 VACCINATION}

Nowadays, biotechnologies are regarded as one of the possible drivers for the innovative economy. That is why the issue of vaccination was rather urgent on the Russian COVID-19 agenda. The issue was debated by international experts, politicians, doctors, and patients. Are the Russians ready for the new post-pandemic reality? Will they agree to obligatory vaccinations and bio-passports?

Now, Russia is a world leader in the COVID-19 testing coverage. And a large population is not the only reason; detecting a maximum number of cases is a national strategy. Though the lockdown measures are over in the majority of Russian territories, regions are still keeping or even increasing the testing coverage. Partly, it helps to hold the number of infected people down. According to the head of the Federal Service for Surveillance on Consumer Rights Protection and Human Wellbeing Anna Popova, less than 1 percent of coronavirus infected people in Russia died.

It should be noted that the Official List of the Most Dangerous Infectious Diseases was reviewed in Russia at the beginning of 2020. A new item 16 was added - "coronavirus disease" (2019-nCoV, the ICD 10 code is B34.2) $)^{12}$. Thus, COVID-19 was deemed a severe, infectious, and quickly spreading human disease with high mortality and disability rates.

11 The Review of the Judicial Practical Issues Related to the Application of the Law and the Measures to Combat the New Coronavirus Disease (COVID -19) in the Russian Federation. Available in: https://vsrf.ru/files/28856/.

12 See the Decree of the Government of the Russian Federation of December 1, 2004 No 715 (addition of January 31, 2020, No. 66). 


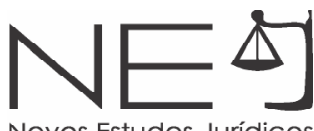

The World Health Organization claimed that in summer 2020, more than 120 companies from various countries were busy with developing a COVID-19 vaccine. More than 10 medications were only at the first phase of clinical trials at that time.

At the same time, it was reported that scientists from the Gamaleya Research Center for Epidemiology and Microbiology under the Russian Health Ministry developed a COVID-19 vector vaccine in May 2020. Some employees of the Institute voluntarily tried the new drug ${ }^{13}$. Alexander Gintsburg, the director of the Center explained that the vaccine is based on adenoviral DNA with a built-in coronaviral gene SARS-CoV-2.

The Association of Clinical Trials Organizations (ACTO) ${ }^{14}$ called the trial of the vaccine in the Gamaleya Center "an ethical breach". They claimed that the Russian scientists had entered a crazy race, wishing to please Mr. Putin. The point was that in mid-April, the Russian President had ordered the government to speed up the clinical trials of coronavirus vaccines. About a month later, the Deputy Prime Minister Tatiana Golikova said that the Russian experts were working on approximately 47 COVID vaccines.

In their public call to the Health Minister Mikhail Murashko, the ACTO experts expressed their joint opinion on the "unofficial coronavirus vaccine trial". The document emphasized "a clearcut violation of the basic principles of clinical trials, Russian legislation, and international law" ${ }^{\prime \prime 15}$. Social networks users announced that there were unapproved experiments on people, which are prohibited by law.

In Russia, under the Federal Law on Circulation of Medicines of April 12, 2010, "an international multicentre clinical trial of a medicinal product for medical use in the Russian Federation or a postregistration clinical trial of a medicinal product for medical use shall be carried out under a permit to conduct a clinical trial of the medicinal product issued by the authorized federal executive body upon the results of the expert examination of the documents required for obtaining a permit to conduct an international multicentre clinical trial of the medicinal product or post-registration clinical trial of the medicinal product and ethical expert examination" (Article 39 (1)). Under Article 43 of the Law, "participation of patients in a clinical trial of a medicinal product for medical use shall be voluntary. The patient or his/her legal representative shall be informed in writing of the following: medicinal product for medical use and the nature of the clinical trial of this medicinal product; safety, anticipated efficacy of the medicinal product for medical use, and the degree of risk for the patient; conditions of the patient's participation in the clinical trial of the medicinal product for medical

13 For more information see: <http://www.gamaleya.ru/>.

14 The ACTO is a Russian non-profit organization of domestic clinical research market participants. The members of the organization are such pharmaceutical companies as Pfizer, AstraZeneca, Bayer, etc. Overall, the ACTO unites 25 companies, pharmaceutical manufacturers, and contract research agencies. The official website: http://actorussia.org/.

15 The ACTO public call on the 'unofficial coronavirus vaccine trial' in the Gamaleya Center. Available in: http://actorussia.org/index.php?option=com_content\&task=view\&id=400. 
use; objective(s) and duration of the clinical trial of the medicinal product for medical use; patient's actions in the event of unforeseen effects of the medicinal product for medical use on the patient's health; terms and conditions of compulsory life and health insurance for the patient; guarantees of confidentiality for the patient's participation in the clinical trial of the medicinal product for medical use. The patient's voluntary consent to participate in the clinical trial of a medicinal product for medical use shall be confirmed by his/her signature or signature of his/her legal representative on the patient information sheet"16. As you see, there are a lot of requirements.

According to the ACTO, there was no official permit to conduct a clinical trial of the coronavirus vaccine on the Gamaleya Center employees. There were no examinations required by law. Besides, the Gamaleya Center employees, who tested the vaccine, were not informed about the nature of the trial and the degree of risk.

Under Article 44 of the Law, "the institution which has obtained a permit for the organization of a clinical trial of a medicinal product for medical use shall ensure the life and health of the patient involved in a clinical trial of a medicinal product at its own expense as an insurant by making a contract for compulsory insurance" ${ }^{\prime 17}$.

As you understand, the participants of the Gamaleya Center experiment were not insured. As it became known, the employees of the Gamaleya Center (developers and technologists) injected the experimental drug on their own at the stage of pre-clinical trials to protect themselves during the pandemic and continue working on the vaccine. But a Russian virologist, Doctor of Medicine Anatoly Alstein noted that a person with coronavirus could be dangerous to people for about two weeks and nothing, including a vaccine, could protect from re-infection. "Vaccination only increases the chances of staying healthy"18. It is worth mentioning that Russia has ratified the standards of the International Council for Harmonization of Technical Requirements for Pharmaceuticals for Human Use (ICH), Good Clinical Practice (GCP), and similar documents. The notion of "vulnerable subjects" turned up in Russian virology. These are the people who may be variously forced to take part in a trial and even be sanctioned if they refuse (for example, medical students, junior staff in clinics and laboratories, employees of pharmaceutical companies, etc.).

"Vulnerable groups" are mentioned in the Declaration of Helsinki (Article 20) ${ }^{19}$. It says that medical research with a vulnerable group is only justified if the research is responsive to the health needs or priorities of this group and the research cannot be carried out in a non-vulnerable group.

16 Russian Federation Law on Circulation of Medicines. Available in: http://www.consultpharma.ru/index.php/en/ documents/drugs/152-61fz.

17 Russian Federation Law on Circulation of Medicines. Available in: http://www.consultpharma.ru/index.php/en/ documents/drugs/152-61fz.

18 A virologist estimated the probability of being infected from a person with a history of COVID-19. Available in: https://ria.ru/20200915/koronavirus-1577253215.html.

19 WMA. Declaration of Helsinki - Ethical Principles of Medical Research Involving Human Subjects. Available in: www.wma.net/policies-post/wma-declaration-of-helsinki-ethical-principles-for-medical-research-involving-humansubjects/. 
Besides, this group should stand to benefit from the knowledge, practices, or interventions that result from the research. Article 35 of the Declaration says that every research study involving human subjects must be registered in a publicly accessible database before recruitment of the first subject ${ }^{20}$.

Vitaly Zverev, the head of the Molecular and Biotechnological Laboratory under the Mechnikov Research Institute for Vaccines and Sera, confirmed that very often Russian medication developers first test their inventions on themselves. Nevertheless, all such trials should be accompanied by corresponding protocols as well as approved by ethical committees and other authorities. What happened in the Gamaleya Center was not only against international standards but also set a bad example for those who are eager to experiment in the same way. COVID 19 is unpredictable. Nontested coronavirus vaccines can make the disease more severe or even result in the patient's death. Alexander Chepurnov, an ex-head of the Extremely Dangerous Infections Laboratory under the State Research Center of Virology and Biotechnology VECTOR, recounted that there was a tradition for every scientist to try a vaccine he/she was developing on himself/herself. Mr. Chepurnov said that once he had been working on a Marburg virus disease vaccine and he had tried it on himself five times. Later it became clear that the vaccine was "dirty" and could trigger the opposite effect, i.e. contribute to the disease ${ }^{21}$. Under the new Government Decree of April 3, 2020 No. 441, all the medicines, used due to an emergency or for preventing and treating life-threatening illnesses, will be registered in Russia under a simplified procedure. From the legal and ethical viewpoints, we are rather critical about this decision. The decision means that now it is possible to file incomplete clinical documentation and register a drug just on the grounds of pre-clinical trials, i.e. when positive results are achieved after animal testing. The task force under the Russian Health Ministry has got the right to cut the number of laboratory examinations and substitute laboratory expertise with simpler trials. Thus, after not very complex trials a drug can go to people. It is also possible to file clinical documentation online. If a drug was previously registered in the US or EU, the Russian registration procedure would be even simpler than that. Finally, the Decree in question allows using medications just with the permission of a medical commission. The commission has only to confirm the effectiveness of a drug ${ }^{22}$.

Another dangerous practice is the widespread use of hydroxychloroquine within the COVID-19 prevention program in Moscow. The experts are seriously concerned because the drug's safety profile contains high and potentially fatal risks to the heart rhythm of a person who takes it. According to the report on the progress of the COVID-19 prevention program, more than 4,000 health workers were at unnecessary risk for several months because their work was based on the Russian Health Ministry's guidelines. The Ministry's guidelines on COVID-19 got outdated very quickly and nobody renewed them. Hospitals and doctors put the lives and health of their patients at risk, following the outdated guidelines ${ }^{23}$.

20 WMA. Declaration of Helsinki - Ethical Principles of Medical Research Involving Human Subjects. Available in: www.wma.net/policies-post/wma-declaration-of-helsinki-ethical-principles-for-medical-research-involving-humansubjects/.

21 See the interview on /www.bbc.com/russian/news-52772808.

22 For more information see: http://www.garant.ru/news/1361745/\#ixzz6YzHN9mDX.

23 For more information see: <http://acto-russia.org/index.php?option=com_content\&task=view\&id=407>. 
In the early autumn of 2020, the Health Ministry published the eighth version of the Temporary Guidelines on Prevention, Diagnosis, and Treatment of COVID-19. However, the dangerous substance called hydroxychloroquine is still being used in the treatment of patients with mild and medium forms of the disease. The guidelines recommend preventing COVID-19 in adults through the Sputnik $V$ vaccine developed in the Gamaleya Center and this recommendation is controversial from the legal viewpoint. Sputnik V is recommended even for people who have neither coronavirus nor antibodies to SARS-Cov-2 ${ }^{24}$. The eighth version of the Guidelines advises first to immune the representatives of the following groups: 1) health workers, teachers, police officers, public transport staff, retailers, social welfare workers, fast food employees, and other employees, contacting with the clients in hotels, hairdressers, barbershops, laundries, banks, etc.; 2) students in educational institutions of all levels; 3) subjects to conscription.

Finally, we will describe another controversial issue with lots of legal, international, and ethical aspects. The development of the Sputnik V vaccine was finished in the Gamalaya Center on July 20, 2020. The Ministry of Defense announced that clinical trials were over; the vaccine had been tested on about 40 volunteers. On August 12, 2020, the medication was registered ${ }^{25}$. However, the Registration Certificate, issued pursuant to the above-mentioned Government Decree No 441, had been obtained before the clinical trials started. This fact is, for sure, against the international legal practice. The Russians consider the registration of the vaccine to be valid up to the beginning of 2021 in case a large-scale phase 3 clinical trial, involving 40,000 volunteers, begins.

Anyway, the Russian Sputnik $V$ was the first registered coronavirus vaccine in the world. Vladimir Putin emphasized this fact and said that he knew, the vaccine worked rather effectively, formed a stable immunity, and passed all the necessary inspections. The President also insisted that vaccination in Russia should only be carried out on voluntarily. In addition, Mr. Putin's daughter and several Government Ministers tested the vaccine on themselves. By early autumn 2020, the third and final phase 3 trials were already in progress. Thousands of people in Moscow and the Moscow region were involved. The first shipments of the drug reached all Russian constituencies to immune people from the risk groups.

In legal terms, we are critical about the fact that the Russian Direct Investment Fund has made verbal agreements with about 50 countries (Brazil, Mexico, India, Middle East countries, etc.) to supply the Sputnik V vaccine to them. According to Western experts, the Russian drug has not been tested enough to prove that it is really effective and safe. It is too soon to use it, especially when all the necessary procedures have not been followed. And there is an ethical point... People now have the medication to protect themselves against COVID-19 but it is still unknown whether it is effective and safe.

24 For more information see: <http://www.garant.ru/news/1409860/\#ixzz6YzJYkX1c>.

25 For more information see: <http://grls.rosminzdrav.ru/Grls_View_v2.aspx?routingGuid=d494c688-0bc6-4c309e81-23f043ceb43e\&t=\%C2\%A0>. 
Against this backdrop, on September 04, 2020, the Lancet, a respected medical journal, published the results of the 2-phase trial of the vaccine conducted in Russia ${ }^{26}$. On September 21, 2020, the journal published an open letter from the international group of health workers and researchers led by Professor Enrico Bucci from Temple University. The foreign experts paid attention to some statistical inconsistencies in the Russian scientists' studies. In particular, the antibody levels in the blood of different participants coincided after immunization ${ }^{27}$. There are two steps in the trials of any vaccine: a pre-clinical step (animal testing) and a clinical step (human subject research). The details of the Russian vaccine animal testing have not been published yet. The criticized article in the Lancet journal was submitted by the Russian vaccine developers and based on the volunteer clinical trials. Then, the Russian scientists responded to the criticism. They admitted that there were not so many participants but they did not explain why the number of participants was so small. And they did not explain why the first and the second phases of the trial were combined ${ }^{28}$. To be honest, all the other COVID-19 vaccines are being developed and tested on samples that are more reliable.

Another shortcoming, restricting the citizens' rights during the pandemic, was a flawed system of online medical services. For example, during the lockdown and distance working it was a problem to get a sick leave online. Under the new Health Ministry Order ${ }^{29}$, during a lockdown (quarantine) or when there is a threat of dangerous diseases, a person can get a sick leave for the whole quarantine period. It should be noted that a sick leave can be registered online only by a federally registered doctor, working in a federally registered medical facility. It is done for fraud prevention.

A kind of guarantee that the medications, used during a pandemic, are safe is the information letter from the Federal Service for Surveillance in Healthcare (FSSH) ${ }^{30}$. It is about probable side effects or inefficacy of COVID-19 vaccines. The FSSH reminds the citizens that it is necessary to inform the relevant authorities about every instance of an unwanted reaction or the absence of a therapeutic effect from a COVID vaccine.

\section{HUMAN RIGHTS IN THE CONTEXT OF LEGAL REGIME OF COVID-19}

In conclusion, we will focus on the problem of restricting human rights in the context of legal regime changes under the influence of COVID-19. Unlike other countries, Russia did not introduce a "high-alert mode" or "emergency mode", which is possible under the Federal Law on Emergencies (Article 8).

26 LOGUNOV, D.Y; DOLZHIKOVA, I.V; ZUBKOVA, O.V. et al. Safety and immunogenicity of an rAd26 and rAd5 vector-based heterologous prime-boost COVID-19 vaccine in two formulations: two open, non-randomized phase 1/2 studies from Russia. Lancet, 2020, Sept 4.

27 BUCCI, E; ANDREEV, K; BJÖRKMAN, A. et al. Safety and Efficacy of the Russian COVID-19 vaccine: more information needed. Lancet, 2020, Sept 21.

28 LOGUNOV, D.Y; DOLZHIKOVA, I.V; TUKHVATULLIN, A. I. et al. Safety and Efficacy of the Russian COVID-19 vaccine: more information needed. Lancet, 2020, Sept 21.

29 The Order of the Russian Health Ministry on the Registration of Sick Leaves Online of September 1, 2020.

30 The Information Letter from the Federal Service for Surveillance in Healthcare on COVID vaccines safety of August 31, 2020. 
Consequently, additional rules for the Russian citizens (restrictive measures) could not be legitimately introduced at the will of local authorities. Nevertheless, the decrees of regional governors and mayors of federal cities were passed to save the population and territories from emergencies.

If a "high alert mode" or an "emergency mode" had been introduced by a presidential decree in the whole country or a particular region, it would have only been possible to restrict the access of people and vehicles to certain places. In fact, the measures, restricting human rights and freedoms are prohibited by law. However, in many regions, the citizens' right to freedom of movement was restricted, e.g. even uninfected people were prohibited from walking outside (in parks, etc.). In some Russian regions, the authorities did not care that according to the WHO, the coronavirus infection was not transmitted by air. On the contrary, in some European countries, a daily one-hour walk in a park was even recommended. In addition, under Article 27 (1) of the Russian Constitution, every person has the right to move freely and choose where to be.

Some regional prescriptions contradicted Article 11 of the Federal Law on Emergencies ${ }^{31}$. Moreover, these by-laws contradicted the Presidential Decree of April 2, 2020 No 239. By the Decree, the restrictive and other measures could be implemented till April 30, 2020, inclusive. That is why we believe that to exceed the term was illegal. It was no less illegal to set up an indefinite ("endless") period, during which human rights could be restricted, especially the rights of uninfected citizens.

Under Article 8 of the Law on the Citizens' Right to Free Movement and the Choice of Residence, this right can be restricted in an emergency case when there is a danger of mass diseases and poisoning. Anyway, the restriction is allowed only by the federal legislation.

The new Presidential Decree of April 28, 2020 No 295 specified that regional senior officials had to take measures to provide for the sanitary and epidemiological welfare in the context of COVID-19 from 1 through 11 May 2020.

At the same time, the Sanitary Regulations of the Russian Federation do not prescribe the restrictions in relation to healthy people, i.e. for the citizens who are uninfected and non-dangerous to everybody around.

In the case of a pandemic, the Russian legislation allows to apply the so-called "measures of social disunity". These are a temporary shutdown of catering facilities, retailers (except essential commodities sellers); a switch to remote working and distance learning; restrictions on public events (or complete prohibition); anti-epidemic regimes in hospitals, schools, and penitentiaries; obligatory use of disinfectants, masks, and gloves, etc.

31 See, for example, the Decree of the Moscow Mayor on the High-Alert Mode of March 5, 2020; the Order of the Moscow Region's Governor on the High-Alert Mode for the Governmental Bodies and Emergency Management Forces to Combat COVID-19 in the Moscow Region of March 20, 2020; the Decree of the Saratov Region's Governor of April 10, 2020. 
The Russian Administrative Code has been amended and now there are sanctions for ignoring the behavioral norms in an emergency or when there is a threat of emergency (Article 20.6.1). The Article covers both federal and regional restrictions. The violation of sanitary and epidemiological restrictions is described in Article 6.3 (2). So, it is impossible to impose a penalty under both Articles for the same violation. Article 6.3 (2) is applied where, for example, people must be quarantined but they are walking in a park. We believe that the use of Article 6.3 (2) to sanction healthy people is illegal.

\section{CONCLUSION}

At the end of our critical overview of the Russian measures to support people and businesses in the context of COVID-19, we believe that a serious restriction of human rights is unacceptable unless it is about an emergency. The serious COVID-19 measures should have been introduced without breaching the constitutional principles of transparency, proportionality, reasonableness, necessity, sufficiency, etc. The universal international legal institutions establishing special rights for vulnerable groups will continue to be applied by member states in the context of a situational response to the global needs of families, women and children, international migration, armed conflicts, environmental conditions, and bioethical issues.

\section{REFERENCES}

BUCCI, E; ANDREEV, K; BJÖRKMAN, A. et al. Safety and Efficacy of the Russian COVID-19 vaccine: more information needed. Lancet, 2020, Sept 21.

LOGUNOV, D.Y; DOLZHIKOVA, I.V; TUKHVATULLIN, A. I. et al. Safety and Efficacy of the Russian COVID-19 vaccine: more information needed. Lancet, 2020, Sept 21.

LOGUNOV, D.Y; DOLZHIKOVA, I.V; ZUBKOVA, O.V. et al. Safety and immunogenicity of an rAd26 and rAd5 vector-based heterologous prime-boost COVID-19 vaccine in two formulations: two open, nonrandomized phase 1/2 studies from Russia. Lancet, 2020, Sept 4.

MALINOVSKY, A. A; OSINA, D.M; TRIKOZ, E.N; State Support for the Russian Economy Affected by Covid-19 Consequences (Legal Aspects), in ASHMARINA, S; MANTULENKO, V; VOCHOZKA, M. (eds). Engineering Economics: Decisions and Solutions from Eurasian Perspective. Engineering Economics Week 2020, Lecture Notes in Networks and Systems, vol. 139, Cham: Springer. 2021, p. 283-287.

WMA. Declaration of Helsinki - Ethical Principles of Medical Research Involving Human Subjects. Available in: www.wma.net/policies-post/wma-declaration-of-helsinki-ethical-principles-for-medical-research-involvinghuman-subjects/.

YASTREBOVA, S; MAREMINSKAYA, E. The Prolongation of the Non-Working Days Period Can Lead to Job Cuts and Bankruptcies, in Vedomosti, April 2, 2020.

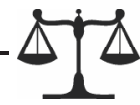

